\title{
SOSIALISASI TENTANG KUALITAS TIDUR PADA SISWI SMAN 1 TALANG KELAPA TAHUN 2021
}

\author{
Atma Deviliawati ${ }^{1}$, Dewi Sayati ${ }^{2}$ \\ ${ }^{1,2}$ Dosen Program Studi Kesehatan Masyarakat Sekolah Tinggi Ilmu Kesehatan Bina Husada \\ Email: atm_2vi@yahoo.co.id, atic_idkisumsel@yahoo.co.id
}

\begin{abstract}
ABSTRAK
Angka prevalensi insomnia di Indonesia adalah 10\% dari jumlah penduduk dan jumlah populasi atau sekitar 28 juta orang, tingginya angka insomnia tersebut, dikaitkan dengan bertambahnya permasalahan yang terjadi dalam kehidupan, seperti depresi dan kecemasan pada seseorang, sedangkan ancaman bahaya kurang tidur dapat memperburuk kondisi kesehatan tubuh, kulit terlihat lebih tua, hilang fokus saat berkendara, munculnya obesitas, stres meningkat, sering lupa dan hilang konsentrasi belajar. Tujuan dari sosialisasi ini mengedukasi siswi tentang kualitas tidur terutama di masa remaja. Metode yang digunakan dengan memberikan sosialisasi secara online dengan membagikan leaflet. kegiatan dilaksanakan pada tanggal 15 Januari 2021. Hasil sosialisasi didapatkan data tentang kualitas tidur sebelum diberi sosialisasi siswi berpengetahuan baik sebanyak 6 orang (14\%), setelah dilakukan sosialisasi terjadi peningkatan siswi yang memiliki berpengetahuan baik tentang kualitas tidur sebanyak 39 orang (93\%), sehingga dari 6 orang atau $14 \%$ yang memiliki pengetahuan baik meningkat menjadi 33 orang atau $79 \%$, menunjukkan bahwa ada peningkatan pengetahuan tentang kualitas tidur sebelum dilakukan sosialisasi dan sesudah dilakukan sosialisasi. Saran kepada penyelenggara pendidikan untuk melakukan edukasi secara terjadual kepada semua siswa mengenai kualitas tidur walaupun lewat media leaflet.
\end{abstract}

Kata kunci: Sosialisasi, Kualitas Tidur, Pengetahuan

\section{SOCIALIZATION ABOUT SLEEP QUALITY ON STUDENTS SMAN 1 TALANG KELAPA IN 2021}

\begin{abstract}
The prevalence rate of insomnia in Indonesia is $10 \%$ of the total population and population of around 28 million people, the high rate of insomnia is associated with increasing problems that occur in life, such as depression and anxiety in a person, while the threat of lack of sleep can worsen health conditions. body, skin looks older, lost focus when driving, the appearance of obesity, increased stress, frequent forgetfulness, and loss of learning concentration. The purpose of this socialization is to educate students about sleep quality, especially in adolescence. The method used is by providing online socialization by distributing leaflets. The activity was carried out on January 15, 2021. The results of the socialization obtained data about the quality of sleep before being given the socialization of knowledgeable students as many as 6 people (14\%), after the socialization there was an increase in students who had good knowledge about sleep quality as many as 39 people (93\%), so that from 6 people or 14\% who had good knowledge, it increased to 33 people or $79 \%$, indicating that there was an increase in knowledge about sleep quality before socialization and after socialization. Suggestions for education providers to carry out scheduled education to all students about the quality of sleep even though through the leaflet media.
\end{abstract}

Keywords: Socialization, Sleep Quality, Knowledge

\section{PENDAHULUAN}

Terdapat dua konsep perkembangan remaja, yaitu nature dan nurture. Konsep nature mengungkap bahwa remaja adalah masa badai dan tekanan. Periode perkembangan ini individu banyak mengalami gejolak dan tekanan karena perubahan yang terjadi pada dirinya (Rosyida, 2019). Perubahan yang terjadi pada remaja perempuan yaitu mengalami menstruasi, menstruasi adalah peristiwa luruhnya sel ovum matang yang tidak dibuahi bersamaan dengan dinding endometrium yang robek. Dapat diakibatkan juga 
karena berhentinya sekresi hormon estrogen dan progesteron sehingga kandungan hormon dalam darah menjadi tidak ada (Rohan, 2017).

Remaja yang telah mengalami mentruasi setiap bulan, tidak sepenuhnya paham mengenai masalah menstruasi, seringkali masalah-masalah yang menyertai menstruasi dianggap sebagai sesuatu yang wajar, dan banyak anggapan-anggapan yang salah di masyarakat dan hal ini mempengaruhi pengetahuan remaja (Mulyaningsih dan Kurniati, 2018). Pada sekitar 14 persen perempuan antara usia 20 hingga 35 tahun, sindrom pramentruasi dapat sangat hebat pengaruhnya sehingga mengharuskan mereka beristirahat dari sekolah atau kantornya. Sindrom ini biasanya lebih mudah terjadi pada wanita yang lebih peka terhadap perubahan hormonal dalam siklus haid (Sibagariang, 2016).

Studi epidemiologi di Ethiopia menunjukkan 49\% remaja mengalami kualitas tidur yang buruk (Lemma,S, 2012 dalam Dhamayanti, 2017). Angka prevalensi insomnia di Indonesia adalah 10\% dari jumlah penduduk dan jumlah populasi atau sekitar 28 juta orang, tingginya angka insomnia tersebut, dikaitkan dengan bertambahnya permasalahan yang terjadi dalam kehidupan, seperti depresi dan kecemasan pada seseorang (Life \& Style, 2017 dalam Zahara, dkk, 2018).

Pola tidur yang dijalani sebagian besar orang adalah tidur selama beberapa jam dalam satu waktu tertentu, usia 12-18 tahun menjelang remaja sampai remaja kebutuhan tidur yang sehat adalah 8-19 jam, studi menunjukkan bahwa remaja yang kurang tidur, lebih rentan terkena depresi, tidak fokus dan punya nilai sekolah yang buruk (Kemenkes, 2016). Kurangnya durasi tidur pada remaja putri berhubungan secara singnifikans dengan kejadian menstruasi yang lebih dari 7 hari (Liu X, 2017 dalam fauzia, dkk 2018), sedangkan ancaman bahaya kurang tidur dapat memperburuk kondisi kesehatan tubuh, kulit terlihat lebih tua, hilang fokus saat berkendara, munculnya obesitas, stres meningkat, sering lupa dan hilang konsentrasi belajar (Kemenkes, 2016).

Penelitian yang dilakukan Nilifda (2016), dari 177 responden 51 mahasiswa (65\%) memiliki kualitas tidur baik dan prestasi akademik yang baik, 27 mahasiswa (35\%) memiliki kualitas tidur yang baik dengan prestasi akademik yang kurang baik, 43 mahasiswa (43\%) memiliki kualitas tidur yang buruk dengan prestasi akademik yang baik dan 56 mahasiswa memiliki kualitastidur yang buruk dan prestasi akademik yang kurang baik. Penelitian yang dilakukan oleh Deaneva, dkk tahun 2014 dari 60 responden didapatkan 34 mengalami kualitas tidur buruk dan 26 orang dengan kualitas tidur baik.

Hasil penelitian yang peneliti lakukan di SMAN 1 Talang Kelapa bulan Desember Tahun 2020 yang lalu di dapatkan dari 42 responden penelitian sebanyak 9 siswi atau $21 \%$ memiliki kualitas tidur yang buruk. Berdasarkan latar belakang diatas maka penulis tertarik untuk melakukan penyuluhan tentang "Kualitas Tidur pada siswi SMAN 1 Talang Kelapa Tahun 2021". Tujuan kegiatan adalah setelah dilakukan penyuluhan tentang kualitas tidur, siswi SMAN 1 Talang Kelapa dapat memahami pentingnya tidur yang berkualitas.

\section{MASALAH}

Ditemukan siswi yang memiliki kualitas tidur buruk sebanyak 9 orang atau $21 \%$ dari 42 responden penelitian yang dilakukan pada bulan Desember tahun 2020, sedangkan ancaman bahaya kurang tidur 
dapat memperburuk kondisi kesehatan tubuh, kulit terlihat lebih tua, hilang fokus saat berkendara, munculnya obesitas, stres meningkat, sering lupa dan hilang konsentrasi belajar

\section{METODE PELAKSANAAN}

Sebelum pelaksanaan pengabdian masyarakat, yang dilakukan secara online via whatshapp, terlebih dahulu melakukan koordinasi untuk perizinan dengan pihak sekolah melalui surat resmi. Bahan yang akan digunakan dalam pengabdian masyarakat handphone, laptop, lembar kuesioner, dan leaflet. Pengabdian masyarakat dilaksanakan tanggal 15 Januari 2021 secara online yang dihadiri lebih kurang 19 orang. Dimana 1 minggu sebelumnya telah dilakukan pembangian kuesioner untuk mengetahui tingkat pengetahuan responden tentang kualitas tidur. Kemudian melakukan penyuluhan kesehatan dengan cara membagikan leaflet. Setelah 1 minggu dilakukan lagi pembagian kuesioner tentang pengetahuan kualitas tidur, sehingga didapatkan kembali data tentang pengetahuan siswi tentang kualitas tidur. Kegiatan sosialisasi berjalan dengan baik. Peserta membaca materi yang disampaikan lewat hp dan mendokumentasikan kegiatannya.

\section{HASIL DAN PEMBAHASAN}

Hasil sosialisasi didapatkan data tentang kualitas tidur sebelum diberi sosialisasi siswi berpengetahuan baik sebanyak 6 orang ( $14 \%$ ), setelah dilakukan sosialisasi terjadi peningkatan siswi yang memiliki berpengetahuan baik tentang kualitas tidur sebanyak 39 orang (93\%), sehingga dari 6 orang atau $14 \%$ yang memiliki pengetahuan baik meningkat menjadi 33 orang atau $79 \%$, menunjukkan bahwa ada peningkatan pengetahuan tentang kualitas tidur sebelum dilakukan sosialisasi dan sesudah dilakukan sosialisasi.

Proses sosialisasi dapat diartikan sebagai proses belajar seorang anggota masyarakat untuk mengenal, menghayati norma-norma serta nilai-nilai masyarakat sehingga terjadi pembentukan sikap, seperti yang dikatakan Prof.Dr. Nasution (Sitorus 2008). Sosialisasi adalah proses membimbing individu kedalam dunia sosial (Nurmaulidina dan Nasionalita, 2018). Salah satu sosialisasi yang dapat dilakukan mengenai kualitas tidur.

Tidur adalah salah satu kebutuhan fisiologis yang memiliki pengaruh terhadap kualitas dan keseimbangan hidup. Seseorang yang mengalami gangguan dalam siklus tidur, maka fungsi fisiologis tubuh yang lain juga dapat terganggu atau berubah. Kegagalan untuk mempertahankan siklus tidur-bangun individual yang normal dapat mempengaruhi kesehatan seseorang (Potter \& Perry, 2005 dalam Pitaloka 2015.

Fisiologi tidur dibedakan menjadi dua tipe yaitu tidur rapid eye movement (REM) dan Non -REM. Kedua tipe ini ditentukan oleh perbedaan dalam pola electro encephalogram (EEG), gerakan mata, dan tonus otot (CDC, 2008), tidur REM dimulai dengan meningkatnya asetikolin, yang mengaktifkan korteks serebrum sementara bagian otak lain tidak aktif, kemudian tidur REM diakhiri dengan meningkatnya 
serotonin dan norpinefrin serta meningkatkan aktivasi otak depan hingga mencapai keadaan bangun (King LA, 2010), (Wahab, 2017).

Secara umum kualitas tidur yang baik ditentukan oleh karakteristik berikut ; anda langsug tertidur setelah tidur, dalam waktu 30 menit atau kurang. Anda biasanya tidur sepanjang malam, bangun tidak lebih dari sekali per malam, anda dapat tidur sesuai jumlah jam yang disarankan untuk kelompok usia anda, anda tidur kembali dalam waktu 20 menit jika anda bangun. Anda merasa istirahat, pulih dan berenergi setelah bangun di pagi hari (Sleep Foundation, 2020).

Banyak faktor dapat mempengaruhi kualitas maupun kuantitas tidur. Hasil dari beberapa penelitian yang telah dilakukan sebelumnya menunjukkan bahwa seseorang yang mengalami gangguan tidur tidak hanya disebabkan oleh faktor tunggal, melainkan dari beberapa faktor, misalnya seseorang yang memiliki suatu penyakit yang menimbulkan rasa nyeri, mereka akan mengalami gangguan ketika tidur karena merasakan ketidaknyamanan fisik yang berakibat kepada berkurangnya jumlah jam untuk tidur (Alsaadi et al, 2004 dalam Alfi, 2014).

Nowakowski, et al (2013), mengatakan tidur dapat dipengaruhi oleh variasi hormon reproduksi, stress, depresi, penuaan, transisi kehidupan/peran dan faktor lainnya. Banyak ahli mengatakan, gangguan tidur tidak langsung berhubungan dengan menurunnya hormon, namun kondisi psikologis dan meningkatnya kecemasan, gelisah serta emosi yang sering tidak terkontrol akibat menurunya hormon estrogen, bisa menjadi salah satu sebab meningkatnya risiko gangguan tidur (Ariantini dan Hariyadi,2012).

Hasil penelitian Haryati, 2020 menunjukkan bahwa faktor yang mempengaruhi kualitas tidur adalah pola tidur dan stres emosional, sedangkan aktifitas fisik mahasiswa secara statistik tidak mempengaruhi kualitas tidur. Saat kita mengalami kurang tidur, hal pertama yang terimbas adalah masalah ingatan dan konsentrasi. Misal kesulitan menemukan suatu kata atau ungkapan untuk sesuatu yang sedang dipikirkan. Orang juga menjadi lekas marah dan hilang mood. Tidak ada yang benar-benar tahu mengapa kita tidur. Jawaban paling sederhana ialah bahwa tidur memulihkan badan, memulihkan kestabilan. dan membantu kita berpikir lebih baik. Ada beberapa teori mengatakan mimpi dalam tidur malam membantu juga dalam mengkonsolidasikan memori/ingatan (Knowledge Raf, 2017).

\section{KESIMPULAN}

Kualitas tidur sebelum diberi sosialisasi siswi berpengetahuan baik sebanyak 6 orang (14\%), setelah dilakukan sosialisasi terjadi peningkatan siswi yang memiliki berpengetahuan baik tentang kualitas tidur sebanyak 39 orang (93\%), sehingga dari 6 orang atau 14\% yang memiliki pengetahuan baik meningkat menjadi 33 orang atau $79 \%$, menunjukkan bahwa ada peningkatan pengetahuan tentang kualitas tidur sebelum dilakukan sosialisasi dan sesudah dilakukan sosialisasi.

\section{UCAPAN TERIMA KASIH}

Penulis mengucapkan terimakasih kepada STIK Bina Husada Palembang yang telah memberikan fasilitas, sehingga program pengabdian kepada masyarakat ini dapat terlaksana sesuai dengan jadual 
penelitian dan pengabdian masyarakat STIK Bina Husada. Penulis juga mengucapkan terimakasih kepada Kepala Sekolah SMAN 1 Talang Kelapa Bapak Habrin, S.Pd, beserta staf tata usaha yang telah memberikan kesempatan dan memfasilitasi pelaksanaan kegiatan pengabdian kepada masyarakat sehingga dapat terlaksana dengan baik dan sesuai harapan.

\section{DAFTAR PUSTAKA}

Alfi, (2014) .Hubungan Kualitas Tidur Dengan Tekanan Darah Pasien Hipertensi. Jurnal Berkala Epidemiologi. Volume 6 Nomor 1 (2018) 18-26. Diakses melalui www.e-journal.unair.ac.id Ariantini dan Haryadi, (2012). Gangguan Insomnia Pada Mahasiswa Yang Menyusun Skripsi. Jurnal Psikologi Ilmiah. INTUISI 3 (3) (2012). Diakses melalui https://journal.unnes.ac.id.

Deaneva, (2014). Hubungan Kualitas Tidur Terhadap Siklus Menstruasi Pada Dokter Muda Di RSUD Dr. Mawardi Surakarta. Jurnal NEXUS Kedokteran Komunitas Vol 4 No.2 Desember 2015. Diakses melalui https://jurnal.fk.uns.ac.id

Fauziah, dkk, (2018). Asupan Gizi Makro dan Durasi Tidur Pada Remaja Usia 16-18 Tahun dan Hubungannya Terhadap Lama Menstruasi. Jurnal MKMI Vol 15 No.1 Maret 2019. Diakses melalui jurnal. unhas.ac.id

Haryati, (2020). Faktor Yang Mempengaruhi Kualitas Tidur Mahasiswa Fakultas Kedokteran Universitas Halu Oleo. Jurnal medika hutama, vol 1 No 03. 146-155 diakses melalui https;//jurnalmedikahutama.com.

Kemenkes, (2016). Memetik ManfaatTidur. Diaksesmelaluiwww.p2ptm.kemkes.go.id

Knowledge Raf. (2017). Insomnia dan Gangguan Tidur Lainnya. Diakses melalui https://ebooks.gramedia.com.

Mulyaningsih dan Kurniati, (2018). Penyuluhan TentangMenstruasi Dan Permasalahannya di MTSN Mojoagung Jombang. Jurnal Pengabdian Masyarakat Kesehatan, 1 (1), 16-17. Diakses melalui journal.stikespemkabjombang.ac.id

Nilifda, dkk (2016). Hubungan Kualitas Tidur Dengan Prestasi Akademik Mahasiswa Program Studi Pendidikan Dokter Angkatan 2010. Vol 5 No.1 (2016). Diakses melalui jurnal.fk.unand.ac.id.

Nurma ulidina dan Nasionalita, (2018). Pengaruh Sosialisasi Terhadap Pengetahuan Pelajar Mengenai Hoax. CHANNEL. Vol 6 No.1 April 2018 diakses melalui journal.uad.ac.id

Norwakowski,et al, (2013). Tidur dan Kesehatan Wanita. (Sleep and Womens, Health-NCBINIH ) diakses melalui www.ncbi.nim.nih.gov

Rohan.dkk. (2017). Buku Kesehatan Reproduksi. Pengenalan Penyakit Menular Reproduksi dan Pencegahan. Intimedia.Jawa Timur.

Rosyida, 2019.Buku Ajar Kesehatan Reproduksi Remaja Dan Wanita. PT. Pustaka Baru. Yogyakarta. Sibagariang, (2016). Kesehatan Reproduksi Wanita. Edisi Revisi. Trans Info Media. Jakarta

Wahab, (2017). Hubungan Kualitas Tidur dengan Migren Pada Mahasiswa Angkatan 2014 Fakultas Kedokteran Universitas Hasanuddin. Diakses melalui digilib.unhas.ac.id 
Pitaloka, (2015). Hubungan Kualitas Tidur Dengan Tekanan Darah an Kemampuan KonsentrasiBelajarMahasiswa Program StudiIlmuKeperawatanUniversitas Riau.JOM Vol.2 No.2, Oktober 2015.Diaksesmelalui media.neliti.com.

Sleep Foundation, (2020). How To Determine Poor Sleep Quality. Diakses melalui www.sleepfoundation.org.

Zahara, dkk. (2018). Gambaran Insomnia Pada Remaja Di SMK Negeri 2 Pekanbaru. JOM FKp. Vol 5 No. 2 (Juli-Desember) 2018. 